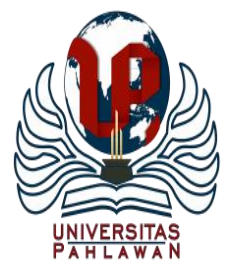

Edukatif : Jurnal Ilmu Pendidikan Volume 3 Nomor 3 Tahun 2021 Halm 871 - 879

EDUKATIF: JURNAL ILMU PENDIDIKAN

Research \& Learning in Education

https:/ledukatif.org/index.php/edukatif/index

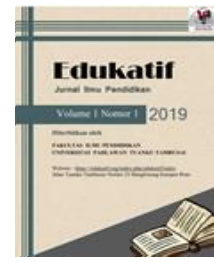

\title{
Penerapan Model Pembelajaran Multiple Intelligences untuk Menyiapkan Siswa di Era Super Smart Society 5.0
}

\author{
Resa Julianti Putri ${ }^{1 凶}$, Taopik Rahman ${ }^{2}$, dan Qonita ${ }^{3}$ \\ Universitas Pendidikan Indonesia, Indonesia ${ }^{1.2 .3}$

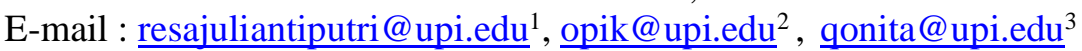

\begin{abstract}
Abstrak
Salah satu hambatan kemajuan dibidang pendidikan adalah pandangan mengenai kecerdasan. Implementasi pendidikan di Indonesia lebih banyak fokus ke bidang kognitif sehingga kecerdasan yang lain terlupakan untuk dikembangkan secara optimal. Seorang siswa harus memiliki kemampuan penunjang untuk menghadapi era society 5.0 tentunya diperoleh dari pendidikan yang memfasilitasi perkembangan semua kecerdasan. Adapun tujuan penulisan artikel ini yakni untuk memaparkan kecerdasan jamak dari sudut pandang neuroscience, model pembelajaran kecerdasan jamak, dan manfaat untuk siswa agar siap menghadapi era society 5.0. Metode yang digunakan yakni theoritcal research, jenis penelitian deskriptif, analisis data melalui model interaktif, dan data diperoleh dari literatur. Hasil pembahasan yakni: (1) neuroscience dapat menjelaskan mengenai kecerdasan jamak secara ilmiah; (2) model pembelajaran kecerdasan jamak terdiri dari pendekatan, strategi, metode, teknik dan taktik; (3) kecerdasan jamak dapat menyiapkan siswa untuk menghadapi era society 5.0. Simpulan dari penulisan artikel ini yakni model pembelajaran berbasis multiple intelligences dapat menyiapkan siswa untuk menghadapi era society 5.0 sehingga diharapkan pembelajaran tidak hanya berfokus pada aspek kognitif saja.
\end{abstract}

Kata Kunci: era society; kecerdasan jamak; model pembelajaran.

\begin{abstract}
One of the obstacles to progress in education is the view of intelligence. The implementation of education in Indonesia focuses more on the cognitive field so that other intelligences are forgotten to be developed optimally. A student must have the supporting abilities to face the era of society 5.0, of course, obtained from education which facilitates the development of all intelligences. The purpose of writing this article is to describe multiple intelligences from the point of view of neuroscience, multiple intelligence learning models, and the benefits for students to be ready to face the era of society 5.0. The method used is theoretical research, descriptive research type, data analysis through interactive models, and data obtained from the literature. The results of the discussion are: (1) neuroscience can explain multiple intelligences scientifically; (2) the multiple intelligence learning model consists of approaches, strategies, methods, techniques and tactics; (3) multiple intelligences can prepare students to face the era of society 5.0. The conclusion from the writing of this article is that the multiple intelligences-based learning model can provide students to face the era of society 5.0 so that it is hoped that learning will not only focus on cognitive aspects.
\end{abstract}

Keywords: era society ; learning model ; multiple intelligences

Copyright (c) 2021 Resa Julianti Putri, Taopik Rahman, Qonita

$\triangle$ Corresponding author

Email : resajuliantiputri@upi.edu

DOI $\quad$ : https://doi.org/10.31004/edukatif.v3i3.415

ISSN 2656-8063 (Media Cetak)

ISSN 2656-8071 (Media Online)

Edukatif : Jurnal Ilmu Pendidikan Vol 3 No 3 Tahun 2021

p-ISSN 2656-8063 e-ISSN 2656-8071 
872 Penerapan Model Pembelajaran Multiple Intelligences untuk Menyiapkan Siswa di Era Super Smart Society 5.0 - Resa Julianti Putri, Taopik Rahman, Qonita

DOI: https://doi.org/10.31004/edukatif.v3i3.415

\section{PENDAHULUAN}

Era super smart society atau dikenal dengan nama era society 5.0 adalah sebuah era yang dicetuskan oleh pemerintah Jepang. Era ini diperkenalkan dalam Forum Ekonomi Dunia yang dilaksanakan di Davos, Swiss pada tahun 2019. (Puspita et al., 2020). Era super smart society adalah sebuah era dimana masyarakat harus bisa menyelesaikan berbagai permasalahan sosial yang diakibatkan oleh penemuan di era industri 4.0 yakni artificial intelligence, internet of things, teknologi robot, hingga big data yang tentunya bisa menggantikan sebagian kebutuhan tenaga manusia (Sawitri, 2019). Untuk menghadapi era ini tentunya pendidik harus menghadirkan konten pembelajaran yang mengajarkan anak didik memiliki kemampuan yang sering disingkat dengan keterampilan 4C yakni critical thingking and problem solving, communication, collaboration, dan creativity and innovation (Prayogi \& Estetika, 2019). Sehingga dalam hal ini tentunya peran pendidikan sangatlah berpengaruh karena pendidikanlah yang akan membentuk dan mengarahkan siswa memiliki kompetensi tersebut untuk menghadapi realitas di abad 21. Adapun sejalan dengan hal tersebut, sebenarnya para tokoh pendidikan Indonesia telah memberikan beberapa gagasan agar siswa siap menghadapi tantangan dan persaingan global. Salah satunya yakni oleh Ki Hajar Dewantara yang memperkenalkan sistem among yakni sebuah sistem yang memberikan kebebasan untuk berpikir (Nurhalita, 2021).

Potret kurikulum pendidikan formal di Indonesia saat ini lebih banyak menekankan pada teoritis generalis daripada aplikasi dan spesialisasi (IDRI), 2020). Hal ini menyebabkan pengembangan kreativitas dan keahlian di bidang IPTEK berjalan kurang baik sehingga pendidikan belum mampu menghasilkan peserta didik yang berkualitas dan siap bersaing. Salah satu alasannya yakni pandangan mengenai kecerdasan. Implementasi pendidikan di Indonesia lebih banyak fokus ke bidang kognitif saja yang lebih menekankan pada pemahaman menulis, membaca, matematika dan ilmu pengetahuan (Adiputri, 2019). Tentunya hal ini membuat pengembangan kecerdasan yang lain terlupakan. Selain itu, kurangnya pemahaman guru mengenai kreativitas mendorong kurikulum yang berkualitas standar dan hanya mengajarkan keterampilan dasar (R. Setiawan et al., 2020).

Pada tahun 1983 Howard Gardner membuat beberapa pengamatan tentang kecerdasan manusia berdasarkan kajian ilmu saraf yang dikumpulkannya selama 35 tahun. Adapun penelitiannya menghasilkan ada tujuh aspek kecerdasan yang kemudian ditambahkannya menjadi delapan kecerdasan yakni "linguistic, logical-mathematical, visual-spatial, bodily-kinaesthetic, musical, inteterpersonal, intrapersonal and naturalist" (Hanafin, 2014). Tetapi pada penerapannya di Indonesia ditambahkan menjadi sembilan kecerdasan yakni kecerdasan spiritual (Sujiono, 2013). Manfaat dari teori Multiple Intelligences yakni dapat menolong siswa dan guru lebih memahami kemampuan siswa "It helps students to build up confidence as it demonstrates how they can use their strengths to address their weaknesses" (UKEssays, 2018) Adapun teori ini muncul sebagai cara pandang baru terhadap hakikat peserta didik didalam pendidikan. Peneliti sebelumnya telah mengungkapkan bahwa teori ini tidaklah sekedar teori, tetapi didasari dengan alasan yang kuat mengapa teori ini harus diterapkan dalam pendidikan. Pertama, teori ini didasarkan pada berbagai hasil riset mengenai potensi yang dimiliki setiap orang. Kedua, dalam teori ini Gardner tidak hanya menawarkan hal yang bersifat teoritis tetapi juga hal yang bersifat praktis karena teori ini telah dicoba di lapangan seperti American Airlines, Bell Atllantic, dan yang lainnya. Ketiga, gagasan ini telah dituangkan secara runtut mulai dari filosofinya hingga sampai penerapan praktisnya. (Husnah, 2019).

Berdasarkan alasan tersebut, maka penelitian ini akan berfokus pada penerapan teori multiple intelligences dalam pendidikan yang kemudian digambarkan dalam model pembelajaran. Model pembelajaran ini terdiri dari pendekatan, strategi, metode dan teknik pembelajaran. Sehingga penelitian ini akan melengkapi penelitian sebelumnya. Dwi Nurani, S,KM, M.Si sebagai analisis pelaksanaan kurikulum pendidikan Direktorat Sekolah Dasar mengungkapkan bahwa untuk menghadapi era society 5.0 satuan pendidikan dibutuhkan adanya perubahan paradigma pendidikan. Diantaranya yakni pendidik meminimalkan peran 
sebagai learning material provider, dan pendidik menjadi penginspirasi bagi tumbuhnya kreativitas peserta didik (Menyiapkan Pendidik Profesional Di Era society 5.0, 2021). Pernyataan tersebut tentunya memberi penekanan bahwa guru harus mengembangkan kreativitas siswa apapun jenis kecerdasan yang dimilikinya. Tetapi saat ini, potret implementasi kurikulum di Indonesia lebih menekankan pada pembelajaran kognitif dan belum memfasilitasi pengembangan semua kecerdasan siswa. Hal ini berakibat pada kurangnya daya saing siswa Indonesia yang dibuktikan dengan tingginya persentase siswa yang tidak berprestasi di Indonesia yakni sebanyak 75 persen pada tahun 2016 (75 Persen Siswa Indonesia Tak Berprestasi, 2016). Dengan demikian, hal ini dapat membuktikan bahwa ada yang salah dari model pembelajaran saat ini. Sehingga hal ini mendorong peneliti untuk mengungkapkan model pembelajaran seperti apa yang akan menyiapkan siswa di era society 5.0. Adapun artikel ini akan memaparkan: (1) apa itu multiple intelligences dari sudut pandang neuroscience; (2) seperti apa model pembelajaran berbasis multiple intteligences; (3) apa manfaat yang akan dihasilkan dari penerapan multiple intteligences untuk siswa agar siap menghadapi era society 5.0 .Dengan demikian, penelitian ini akan menjelaskan model pembelajaran berbasis Multiple Intelligences yang dapat membantu siswa memiliki kompetensi untuk menghadapi era society 5.0.

\section{METODE}

Penelitian ini menggunakan metode theoritical research yang menyajikan informasi melalui sumber yang relevan dengan topik dan bukan menggunakan metode empiris. Adapun jenis penelitian yang digunakan adalah penelitian deskriptif yang menghasilkan gambaran mengenai topik yang diteliti. Teknik analisis data yang digunakan adalah cara Miles \& Huberman dengan model interaktif. Model interaktif ini terdiri dari : (1) collecting data; (2) data reduction; (3) display data; dan (4) conclution. Selain itu, pengumpulan data diperoleh dari proses reviu jurnal ilmiah yang diperoleh dari literatur seperti jurnal ilmiah, buku, esai, dan media cetak lainnya yang sesuai dengan topik yang dikaji.

\section{HASIL DAN PEMBAHASAN}

\section{Konsep Multiple Intelligences dari Sudut Pandang Neuroscience}

Kecerdasan adalah salah satu anugerah Tuhan Yang Maha Esa yang tumbuh dan berkembang seiring faktor tertentu. Setiap manusia diberikan kecerdasan yang tentunya berbeda satu sama lain. Seiring dengan perkembangannya, saat ini di dalam diri manusia tidak hanya ada kecerdasan intelektual (IQ), tetapi terdapat juga kecerdasan yang lain seperti kecerdasan emosional (EQ) dan kecerdasan spiritual (SQ) (Ismail, 2017).

Kecerdasan memang dipandang sebagai sebuah potensi manusia untuk bisa mengambil keputusan dari berbagai permasalahan atau bahkan menghasilkan suatu produk yang bernilai.

Saat ini, para praktisi pendidikan beranggapan bahwa kecerdasan berkaitan dengan keterampilan akademis seperti membaca, matematika, dan lain sebagainya. Salah satu alasan kecerdasan umum dianggap sah yakni karena ada banyak data tes yang dikumpulkan sejak 100 tahun yang lalu misalnya yakni tes IQ yang masih dipakai sampai sekarang (Shearer, 2018).

Howard Gadner sudah mengemukakan bahwa ada kecerdasan lain selain kecerdasan yang bersifat akademis. Macam-macam kecerdasan tersebut yakni kecerdasan logika matematika, kecerdasan musik, bahasa, visual, kinestetik, interpersonal, intrapersonal dan naturalis. Kecerdasan tersebut disebut dengan kecerdasan jamak, tetapi kecerdasan ini seringkali tidak dianggap sah karena tidak ada data yang bisa mengukur kecerdasan tersebut.

Salah satu hal yang bisa menjelaskan mengenai kecerdasan jamak secara ilmiah yakni melalui kajian ilmu saraf (neuroscience). Ada lima prinsip utama dalam membimbing kecerdasan berdasarkan ilmu saraf yakni : (1) pentingnya budaya; (2) setiap otak adalah unik; (3) mengenali diri; (4) kesadaran emosional; dan 
874 Penerapan Model Pembelajaran Multiple Intelligences untuk Menyiapkan Siswa di Era Super Smart Society 5.0 - Resa Julianti Putri, Taopik Rahman, Qonita

DOI: https://doi.org/10.31004/edukatif.v3i3.415

(5) membuat sesuatu berarti (Shearer, 2018). (Shearer, 2018) mengemukakan, hubungan bagian otak manusia dengan kecerdasan jamak yakni dapat dilihat sebagai berikut :

Tabel 1. Kecerdasan Jamak Berdasarkan Neuroscience

\begin{tabular}{|c|c|c|c|c|}
\hline No. & Kecerdasan & Unit Kognitif Inti & Wilayah Utama & Sub Wilayah \\
\hline 1. & Interpersonal & $\begin{array}{l}\text { - Persepsi sosial } \\
\text { - Pemahaman } \\
\text { Interpersonal } \\
\text { - Efektifitas Sosial } \\
\text { - Kepemimpinan }\end{array}$ & $\begin{array}{ll}\text { - } & \text { Frontal } \\
\text { - } & \text { Temporal } \\
\text { - } & \text { Cingulate } \\
\text { - } & \text { Parietal }\end{array}$ & $\begin{array}{l}\text { Media-Temporal } \\
\text { Amygdala } \\
\text { Dorsolateral PFC } \\
\text { Anterior Cingulate } \\
\text { Superior Temporal } \\
\text { Sulcus }\end{array}$ \\
\hline 2. & Intrapersonal & $\begin{array}{ll}\text { - } & \text { Kesadaran diri } \\
\text { - } & \text { Pengaturan diri } \\
\text { - } & \text { Kemampuan } \\
& \text { eksekusi } \\
\text { - } & \text { Pengelolaan diri }\end{array}$ & $\begin{array}{ll}\text { - } & \text { Frontal } \\
\text { - } & \text { Cingulate } \\
\text { - } & \text { Temporal } \\
\text { - } & \text { Parietal } \\
\text { - } & \text { Subcortical }\end{array}$ & $\begin{array}{l}\text { Prefrontal-Cortex } \\
\text { Anterior Cingulate } \\
\text { Dorsomedial PFC } \\
\text { Lateral Prefrontal } \\
\text { Ventromedial }\end{array}$ \\
\hline 3. & $\begin{array}{l}\text { Logika } \\
\text { Matematika }\end{array}$ & $\begin{array}{l}\text { - Penalaran } \\
\text { Matematika } \\
\text { - Penalaran Logika }\end{array}$ & $\begin{array}{ll}\text { - } & \text { Frontal } \\
\text { - } & \text { Parietal } \\
\text { - } & \text { Temporal } \\
\end{array}$ & $\begin{array}{l}\text { Prefrontal } \\
\text { Intraparietal Sulcus } \\
\text { Inferior } \quad \text { Parietal } \\
\text { Lobule }\end{array}$ \\
\hline 4. & Linguistik & $\begin{array}{l}\text { - } \text { Berbicara } \\
\text { - Membaca } \\
\text { - Menulis } \\
\text { - Pemahaman } \\
\text { Multimodal } \\
\text { Komunikasi }\end{array}$ & $\begin{array}{ll}\text { - } & \text { Temporal } \\
\text { - } & \text { Frontal } \\
\text { - } & \text { Parietal }\end{array}$ & $\begin{array}{l}\text { Superior Temporal } \\
\text { Gyrus } \\
\text { Inferior Frontal Gyrus } \\
\text { Broca's Area } \\
\text { Posterior Inferior } \\
\text { Frontal Gyrus }\end{array}$ \\
\hline 5. & Spasial & $\begin{array}{ll}\text { - } & \text { Kognisi spasial } \\
\text { - } & \text { Bekerja dengan } \\
\text { objek } \\
\text { - Seni visual } \\
\text { - Navigasi spasial }\end{array}$ & $\begin{array}{ll}\text { - } & \text { Frontal } \\
\text { - } & \text { Parietal } \\
\text { - } & \text { Temporal } \\
\text { - } & \text { Occipital }\end{array}$ & $\begin{array}{l}\text { Premotor Cortex } \\
\text { Motor Cortex } \\
\text { Medial Temporal } \\
\text { Prefrontal }\end{array}$ \\
\hline 6. & Musikal & $\begin{array}{l}\text { - Persepsi Musik } \\
\text { - Musik dan emosi } \\
\text { - Memproduksi music }\end{array}$ & $\begin{array}{ll}\text { - } & \text { Frontal } \\
\text { - } & \text { Temporal } \\
\text { - } & \text { Subcortical } \\
\text { - } & \text { Cerrebelum }\end{array}$ & $\begin{array}{l}\text { Superior Temporal } \\
\text { Gyrus } \\
\text { Primary Auditory } \\
\text { Cortex } \\
\text { Premotor Cortex } \\
\text { Basal Ganglia } \\
\text { Supplementary Motor }\end{array}$ \\
\hline 7. & Kinestetik & $\begin{array}{l}\text { - Kesadaran tubuh } \\
\text { - Gerakan seluruh } \\
\text { tubuh } \\
\text { - Ketangkasan } \\
\text { - Gerakan Simbolik }\end{array}$ & $\begin{array}{ll}\text { - } & \text { Frontal } \\
\text { - } & \text { Parietal } \\
\text { - } & \text { Subcortical } \\
\text { - } & \text { Cerrebelum }\end{array}$ & $\begin{array}{l}\text { Motor Cortex } \\
\text { Primary Motor Cortex } \\
\text { Premotor Cortex } \\
\text { Basal Ganglia }\end{array}$ \\
\hline 8. & $\begin{array}{l}\text { Kecerdasan } \\
\text { Naturalis }\end{array}$ & $\begin{array}{l}\text { - Pola Kognisi } \\
\text { - Memahami entitas } \\
\text { hidup } \\
\text { - Memahami hewan } \\
\text { - Memahami ilmu } \\
\text { hidup tanaman }\end{array}$ & $\begin{array}{ll}\text { - } & \text { Temporal } \\
\text { - } & \text { Subcortical }\end{array}$ & $\begin{array}{l}\text { Superior Temporal } \\
\text { Sulcus } \\
\text { Amygdala } \\
\text { Brainstem } \\
\text { Thalamus } \\
\text { Midbrain } \\
\text { Basal Ganglia }\end{array}$ \\
\hline
\end{tabular}


Dari tabel tersebut dapat terlihat bahwa ilmu saraf dapat menjelaskan hubungan antara kecerdasan dengan wilayah saraf yang berkembang. Salah satu contohnya yakni seseorang yang memiliki kecerdasan interpersonal, maka saraf yang berkembang yakni di wilayah frontal, temporal, cingulate, dan parietal. Walaupun kecerdasan ini tidak memiliki ukuran kecerdasan berupa angka seperti halnya kognitif, tetapi ilmu saraf dapat menjelaskan kecerdasan jamak ini secara lebih ilmiah.

\section{Model Pembelajaran Berbasis Multiple Intelligences}

Setiap anak memiliki kemampuan yang berbeda satu sama lain. Untuk mengasah dan menghasilkan kreativitas anak harus dimulai sejak dini. Kreativitas ini dibutuhkan manusia untuk menyelesaikan berbagai masalah dalam kehidupan sehari-hari. Adapun untuk mengasah kreativitas anak maka perlu model pembelajaran yang memfasilitasi kebutuhan yang dimiliki oleh setiap anak didik. (A. R. Setiawan \& Ilmiyah, 2020) mengemukakan ada dua dampak langsung terhadap pembelajaran ketika gagasan kecerdasan majemuk diterapkan secara operasional yakni: 1) pelajar diberi banyak cara untuk mengakses informasi ; dan 2) pembelajaran dilakukan secara individual Hal tersebut tentunya mendorong pengembangan kemampuan dan bakat individu, dan siswa diberikan kesempatan untuk belajar sesuai dengan gaya belajar yang tepat.

Adapun model pembelajaran berbasis multiple intelligences dapat dilihat dari skema berikut:

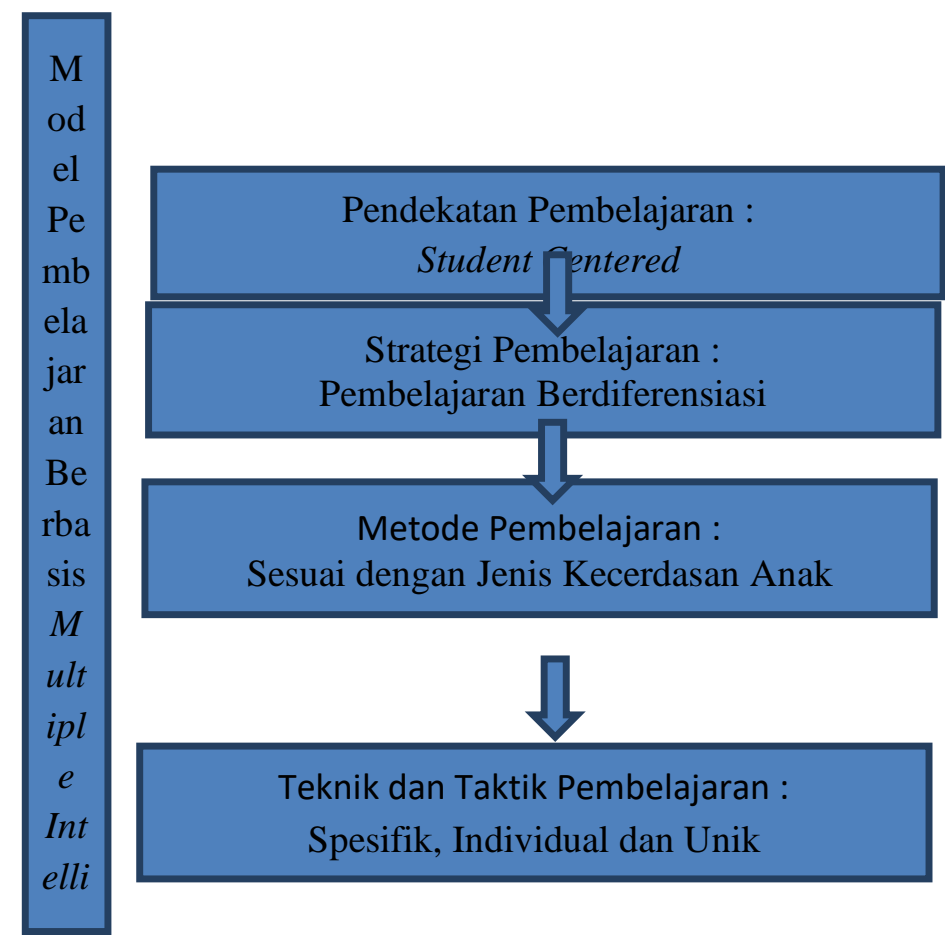

Gambar 1 : Skema Model Pembelajaran Multiple Intelligences

Pendekatan Pembelajaran Multiple Intelligences. Pendekatan yang digunakan adalah student centered. Student Centered Learning (SCL) adalah salah satu pembelajaran yang bebasis pada aktivitas siswa dan menerapkan prinsip learning by doing. (Antika, 2014) menyatakan bahwa murid bukanlah objek pembelajaran dimana guru memberikan informasi, tetapi murid adalah subjek yang memiliki potensi. Potensi inilah yang harus distimulasi dan dikembangkan untuk mencapai kemampuan yang optimal.

Strategi Pembelajaran Multiple Intelligences dilakukan dengan membuat kelas berdiferensiasi. Dalam hal ini peran guru adalah sebagai fasilitator. Ada beberapa hal yang harus dipersiapkan untuk mengimplementasikan kelas berdiferensiasi. Hal ini sejalan dengan pendapat Arends dan Kilcher dalam (Istiningsih \& Nisa, 2015) yakni : a) Melakukan perencanaan. Perencanaan ini dapat dilakukan melalui tiga 
hal yakni: (1) melakukan identifikasi IQ; (2) Setelah mendapatkan hasil dari tes IQ maka selanjutnya menganalisis kemampuan dan kelemahan yang dimiliki siswa ; dan (3) membuat kelompok- kelompok belajar kecil sesuai dengan minat dan kemampuan siswa. Sehingga dalam hal ini siswa tidak ditekankan untuk menguasai hal yang sama. b) Mengatur kelas berdiferensiasi Pengaturan kelas ini dilakukan secara fleksibel yakni ada saatnya siswa untuk melakukan kegiatan secara individu, kelompok kecil ataupun ada saatnya pembelajaran klasikal (bersamaan).c) Penilaian yang tepat dalam kelas berdiferensiasi Penilaian kelas ini terdiri dari penilaian yang dilakukan diawal (diagnostik), penilaian tengah (formatif) dan penilaian akhir (sumatik).

\section{Metode Pembelajaran Multiple Intelligences}

Metode yang digunakan dalam pembelajaran ini disesuiakan dengan setiap kecerdasan. Sejalan dengan (Musfiroh, 2014) sebagai berikut :

Tabel 2. Metode Pembelajaran Setiap Kecerdasan

\begin{tabular}{|c|l|l|}
\hline No. & \multicolumn{1}{|c|}{ Kecerdasan } & \multicolumn{1}{|c|}{ Metode Pembelajaran } \\
\hline 1. & Linguistik (bahasa) & $\begin{array}{l}\text { Dapat dilakukan dengan kegiatan, melihat tulisan, } \\
\text { mendengar, mengucapkan. Misalnya dengan metode } \\
\text { bercerita. }\end{array}$ \\
\hline 2. & Logis-matematika & $\begin{array}{l}\text { Cara belajar yang tepat adalah melalui angka, berpikir, } \\
\text { bertanya mencoba, menduga, menghitung, } \\
\text { menimbang, mengurutkan, mengklasifikasikan dan } \\
\text { mengontruksi. Misalnya dengan metode proyek. }\end{array}$ \\
\hline 3. & Visual Spasial & $\begin{array}{l}\text { Cara belajar melalui warna, coretan, arah, bentuk dan } \\
\text { ruang. Misalnya dengan metode proyek. }\end{array}$ \\
\hline 4. & Musikal & $\begin{array}{l}\text { Cara belajar yakni dengan nada, irama dan melodi. } \\
\text { Misalnya metode demontrasi. }\end{array}$ \\
\hline 5. & Kinestetik & $\begin{array}{l}\text { Cara belajarnya yakni diberikan ruang bergerak dengan } \\
\text { memfasilitasi pengembangan motorik kasar dan halus. } \\
\text { Misalnya dengan metode karyawisata. }\end{array}$ \\
\hline 6. & Interpersonal & $\begin{array}{l}\text { Cara belajarnya yakni dengan interaksi bersama orang } \\
\text { lain. Misalnya dengan metode sosiodrama. }\end{array}$ \\
\hline 7. & Naturalis & $\begin{array}{l}\text { Cara belajarnya bisa dilakukan dengan metode } \\
\text { eksperimen. }\end{array}$ \\
\hline 8. & Intrapersonal & $\begin{array}{l}\text { Cara belajarnya yakni melalui tugas, kepercayaan dan } \\
\text { pengakuan. Misalnya dengan metode pemberian tugas. }\end{array}$ \\
\hline
\end{tabular}

Berdasarkan tabel tersebut dapat terlihat bahwa metode pembelajaran setiap kecerdasan satu dengan lainnya berbeda sehingga hal ini bisa memfasilitasi belajar siswa dengan metode yang tepat sesuai dengan kecerdasan yang dimiliki siswa tersebut.

Selain delapan kecerdasan itu, penerapan di Indonesia ditambah dengan kecerdasan spiritual. Di Indonesia penerapan kecerdasan ini sudah dilakukan sejak dahulu. Hal ini tercermin dari salah satu tokoh pahlawan nasional bernama KH. Ahmad Dahlan. Hal ini diungkapkan oleh (Amelia \& Dahlan, 2021) bahwa K. H. Ahmad Dahlan membawa ilmu agama ke dalam pendidikan modern bukan hanya mengajarkannya kepada siswa, melainkan kepada guru-gurunya juga. Adapun metode yang bisa digunakan untuk mengembangkan kecerdasan ini yakni menggunakan metode ceramah atau bercerita.

1. Teknik dan Taktik Pembelajaran Multiple Intelligences

a. Spesifik

Spesifik maksudnya yakni bersifat khusus. Pembelajaran multiple intelligences dimaksudkan untuk memfasilitasi kecerdasan khusus yang dimiliki seseorang.

b. Individual 
877 Penerapan Model Pembelajaran Multiple Intelligences untuk Menyiapkan Siswa di Era Super Smart Society 5.0 - Resa Julianti Putri, Taopik Rahman, Qonita

DOI: https://doi.org/10.31004/edukatif.v3i3.415

Pembelajaran multiple intelligences ini fokus pada pengembangan individu. Maka dari itu, tidak ada penekanan siswa untuk menguasai semua bidang.

c. Unik

Pembelajaran multiple intelligences bersifat unik karena mengapresiasi setiap kecerdasan siswa. Maka dari itu, tidak akan ada lagi guru yang menganggap siswa kurang cerdas jika tidak bisa pelajaran matematika.

\section{Manfaat Pembelajaran Multiple Intelligences untuk Siswa Menghadapi Era society 5.0}

Multiple Intelligences adalah sebuah jembatan yang menghubungkan antara tuntutan yang harus dihadapi ditengah dunia yang semakin pesat dengan kemampuan siswa yang harus dimiliki. Adanya artificial intelligence, internet of things, teknologi robot, hingga big data yang harus siswa hadapi dengan kemampuan yang harus dimilikinya yakni critical thingking and problem solving, communication, collaboration, dan creativity and innovation.

Seperti halnya diungkapkan oleh (Hohn, 2021) manfaat dari multiple intelligences yakni: Pertama, multiple intelligences memberikan perspektif yang berbeda untuk memecahkan masalah. Kedua, pembelajaran ini bisa melatih siswa membawa hobi kedalam pekerjaannya kelak. Dengan demikian, di tengah perkembangan dunia yang semakin pesat siswa akan mampu menciptakan pekerjaan minimal untuk dirinya sendiri melalui hobi yang dia tekuni. Ketiga, pembelajaran ini akan memberikan banyak substansi untuk melatih kreativitas serta kemampuan sosial. Keempat, pembelajaran ini bisa lebih membuat seseorang mengembangkan diri dan menghargai bakatnya.

Penelitian ini memberikan gambaran mengenai model pembelajaran berbasis multiple intelligence sebagai implementasi dari teori Howard Gardner yang diterapkan dalam pembelajaran. Adapun model pembelajaran yang dikemukakan dalam artikel ini adalah model pembelajaran untuk tingkat dasar seperti Pendidikan Anak Usia Dini dan Sekolah Dasar yang tentunya bisa dikembangkan untuk tingkat yang lebih lanjut.

Adapun penelitian yang dilakukan oleh (Husnah, 2019) mengungkapkan bahwa dengan ditemukannya makna cerdas secara majemuk oleh Howard Gardner, maka dunia pendidikan diharuskan untuk menata ulang tentang pola dan proses pendidikan yang selama ini berjalan, terutama cara pandang terhadap peserta didik.

Dengan dikajinya model pembelajaran ini tentunya akan memberikan paradigma baru untuk kemajuan bidang pendidikan di Indonesia. Sehingga, dunia pendidikan akan mulai menata ulang dan para praktisi pendidikan akan memiliki perspektif baru tentang multiple intelligence. Hal ini didukung juga oleh (Nastiti \& Abdu, 2020) bahwa untuk mneghadapi era society pendidikan harus berbasis kompetensi. Dan multiple intelligence ini memfasilitasi pengembangan kompetensi tersebut seperti kemampuan berpikir kritis, dan kreatif. Tentunya hal ini akan menjadi modal siswa untuk bisa menghadapi era super smart society 5.0.

\section{KESIMPULAN}

Era society 5.0 adalah sebuah era yang mengharuskan pendidikan membekali peserta didik dengan kompetensi yang harus dimiliki oleh siswa seperti critical thingking and problem solving, communication, collaboration, dan creativity and innovation. Model pembelajaran multiple intelligence ini hadir sebagai implementasi dari penerapan teori Howard Gardner mengenai kecerdasan jamak yang memberikan manfaat untuk siswa sehingga memiliki kompetensi yang akan berguna untuk menghadapi era society. Didalam artikel ini multiple intelligence dijelaskan dalam perspektif ilmu saraf (neuroscience) sehingga bisa mematahkan anggapan tidak ilmiahnya teori multiple intelligence dibandingkan kecerdasan lain. Selain itu, pendekatan pembelajaran multiple intelligences yakni student centered. Strategi pembelajaran yang digunakan adalah 
878 Penerapan Model Pembelajaran Multiple Intelligences untuk Menyiapkan Siswa di Era Super Smart Society 5.0 - Resa Julianti Putri, Taopik Rahman, Qonita

DOI: https://doi.org/10.31004/edukatif.v3i3.415

kelas berdiferensiasi, metode yang digunakan disesuiakan dengan cara belajar setiap kecerdasan dan teknik dan taktik yang digunakan bersifat spesifik, individual dan unik. Manfaat multiple intelligences untuk siswa yakni siswa akan bisa memecahkan masalah dari perspektif yang berbeda, dapat menjadikan hobi sebagai pekerjaan, mendukung pekerjaan yang menuntut kreativitas dan membuat seseorang mengembangkan diri dan menghagai bakatnya.

\section{DAFTAR PUSTAKA}

(IDRI), I. D. R. (2020). Menatap wajah Pendidikan Indonesia Di Era 4.0 (A book Chapter of Indonesian Lecturer Assosiations.

75 Persen Siswa Indonesia tak Berprestasi. (2016). JPNN.Com. https://www.jpnn.com/news/75-persen-siswaindonesia-tak-berprestasi?page $=2$

Adiputri, R. D. (2019). Sistem Pendidikan Finlandia. Kepustakaan Populer Gramedia.

Amelia, T. F., \& Dahlan, K. H. A. (2021). EDUKATIF : JURNAL ILMU PENDIDIKAN Pembaharuan Pendidikan Berdasarkan Pemikiran K. H. Ahmad Dahlan Abstrak. 3(2), 472-479.

Antika, R. R. (2014). Proses Pembelajaran Berbasis Student Centered Learning. BioKultur, III(1), 251-263.

Hanafin, J. (2014). Multiple intelligences theory, action research, and teacher professional development: The irish MI project. Australian Journal of Teacher Education, 39(4). https://doi.org/10.14221/ajte.2014v39n4.8

Hohn, H. (2021). The Benefits of Multiple Intelligences. Mantra. https://www.mantra-europe.com/c/multipleintelligences\#lb60483/the-benefits-of-multiple-intelligences

Husnah, Z. (2019). MULTIPLE INTELLIGENCE BASED-EDUCATION Mewujudkan Indonesia sebagai Bangsa Para Juara. Al-Mudarris (Jurnal Ilmiah Pendidikan Islam), 1(2), 51-65. https://doi.org/10.23971/mdr.v1i2.1030

Ismail. (2017). Kecerdasan IQ, EQ, DAN SQ DALAM PEMBENTUKAN KEPRIBADIAN MUKMIN. Kabilah, 2(1), 159-175.

Istiningsih, \& Nisa, A. F. (2015). Implementasi Multiple Intelligences dalam Pendidikan Dasar. Al-Bidayah: Jurnal Pendidikan Dasar Islam, 7(2), 182-196. https://jurnal.albidayah.id/index.php/home

Menyiapkan Pendidik Profesional Di Era society 5.0. (2021). Direktorat Sekolah Dasar. http://ditpsd.kemdikbud.go.id/artikel/detail/menyiapkan-pendidik-profesional-di-era-society-50\#

Musfiroh, T. (2014). Pengembangan Kecerdasan Majemuk. Hakikat Kecerdasan Majemuk (Multiple Intelegences), 1-60. http://repository.ut.ac.id/4713/2/PAUD4404-TM.pdf

Nastiti, F., \& Abdu, A. (2020). Kajian: Kesiapan Pendidikan Indonesia Menghadapi Era society 5.0. Edcomtech Jurnal Kajian Teknologi Pendidikan, 5(1), 61-66. https://doi.org/10.17977/um039v5i12020p061

Nurhalita, N. (2021). EDUKATIF : JURNAL ILMU PENDIDIKAN Relevansi Pemikiran Pendidikan Ki Hajar Dewantara pada Abad ke 21 Abstrak. 3(2), 298-303.

Prayogi, R. D., \& Estetika, R. (2019). Kecakapan Abad 21 : Kompetensi Digital Pendidik Masa Depan. Jurnal Manajemen Pendidikan, 14(2), 144-151. http://journals.ums.ac.id/index.php/jmp/article/download/9486/5193

Puspita, Y., Fitriani, Y., Astuti, S., \& Novianti, S. (2020). Selamat Tinggal Revolusi Industri 4.0, Selamat Datang Revolusi Industri 5.0. Prosiding Seminar Nasional Pendidikan Program Pascasarjana Universitas Pgri Palembang, 122-130. https://jurnal.univpgripalembang.ac.id/index.php/Prosidingpps/article/view/3794/3565 
879 Penerapan Model Pembelajaran Multiple Intelligences untuk Menyiapkan Siswa di Era Super Smart Society 5.0 - Resa Julianti Putri, Taopik Rahman, Qonita

DOI: https://doi.org/10.31004/edukatif.v3i3.415

Sawitri, D. (2019). Jurnal Ilmiah Maksitek ISSN : 2548-429X. Jurnal Ilmiah Maksitek, 3(November), 15-27. https://makarioz.sciencemakarioz.org/index.php/JIM/article/view/83/80

Setiawan, A. R., \& Ilmiyah, S. (2020). Kecerdasan Majemuk Berdasarkan Neurosains. April. https://doi.org/10.35542/osf.io/rj2fe

Setiawan, R., Mardapi, D., Aman, \& Karyanto, U. B. (2020). Multiple intelligences-based creative curriculum: The best practice. European Journal of Educational Research, 9(2), 611-627. https://doi.org/10.12973/eu-jer.9.2.611

Shearer, B. (2018). Multiple intelligences in teaching and education: Lessons learned from neuroscience. Journal of Intelligence, 6(3), 1-8. https://doi.org/10.3390/jintelligence6030038

Sujiono, Y. N. (2013). Konsep Dasar Pendidikan Anak Usia Dini. PT INDEKS.

UKEssays. (2018). Benefits of Multiple Intelligences. https://www.ukessays.com/essays/education/benefits-ofmultiple-intelligence-in-english-language-teaching-education-essay.php?vref=1 